\title{
Aluminum-enhanced alkali diffusion from float glass to PVD-sputtered silica thin films
}

\author{
Jean-Thomas Fonné*, Ekaterina Burov*, Emmanuelle Gouillart*, Sergey Grachev*, Hervé Montigaud* \\ Surface du Verre et Interfaces, UMR 125 CNRS/Saint-Gobain, 93303 Aubervilliers, France \\ Damien Vandembroucq* \\ Laboratoire PMMH, UMR 7636 CNRS/ESPCI/Univ. Paris 6 UPMC/Univ. Paris 7 Diderot, 10 rue Vauquelin, 75231 Paris \\ cedex 05, France
}

\begin{abstract}
Interdiffusion processes between aluminum enriched PVD-sputtered silica thin films and industrial float sodalime silicate glass substrates are quantitatively studied using SIMS analysis. Heat treatments are performed at temperatures close or above the glass transition temperature of the float glass. Aluminum doping of the film is shown to strongly increase the migration of alkali from the glass substrate to the silica thin film. In particular the final alkali content in the film exhibits a linear scaling with the aluminum concentration. An interdiffusion process is evidenced between bulk alkali ions and protons originating from a significant water content in the as-deposited silica film. Experimental measurements of sodium concentration are shown to be consistent with a simple thermodynamic model based on the equilibration of the activity of sodium between the film and the glass substrate.
\end{abstract}

Keywords: Silica thin film, Barrier layer, Alkali-ions migration, Interface diffusion

\section{Introduction}

Industrial glasses coated with thin films are often subjected to thermal treatments, in the framework of a forming process, or in order to enhance specific properties of the glazing, or to improve the mechanical properties of glass. At high temperature close or above the glass temperature of the substrate, several species diffuse from the substrate to the thin films. For soda-lime float glass, the diffusion of sodium or other alkali ions is the most significant effect. Alkali diffusion is beneficial for a minority of active layers, such as $\mathrm{CuGaSe}_{2}$ thin film for solar cells, in which controlled diffusion of sodium and potassium has been shown 1] to enhance energy conversion. However, sodium alters the electrical properties of most active layers used in solar cells [2, 3, 4, 5, with dramatic effects such as electrical shunting caused by the widening of grain boundaries [6. The diffusion of sodium also decreases the

\footnotetext{
*corresponding author: jean-thomas.fonne@saintgobain.com / +33(0)148398556
}

mechanical or electrical properties of low-emissivity coatings [7, 8, used in the building and automotive industry, or of transparent conducting oxide layers used in displays 9 .

In order to limit the diffusion of alkali from the glass substrate to the active layers, barrier layers are deposited on the glass surface [2]. Alkali diffusion through a barrier layer has been studied for a variety of compositions, such as silicon nitride [10, silica, alumina [11, 12] or ceria [13, and for different deposition processes such as chemical vapor deposition (CVD) 14, 15, physical vapor deposition (PVD) 7, 8, or sol-gel coating [16, 17]. One of the most common compositions of barrier layers is silica, which is usually doped with aluminum in PVD coaters in order to increase the deposition rate [18. For non-doped silica thin films, Araujo et al. [19] showed that the chemical potential of sodium in the substrate could be used to predict whether sodium would diffuse from the substrate to the silica layer, or in the other direction in the case of alumina- or boron-rich substrate compositions. 
Table 1: Composition (in weight percent) of the soda-lime glass substrates.

\begin{tabular}{|cc|}
\hline oxides & weight \% \\
\hline $\mathrm{SiO}_{2}$ & 73.0 \\
$\mathrm{Na}_{2} \mathrm{O}$ & 13.5 \\
$\mathrm{CaO}$ & 10.0 \\
$\mathrm{MgO}$ & 2.5 \\
$\mathrm{Al}_{2} \mathrm{O}_{3}$ & 0.5 \\
$\mathrm{~K}_{2} \mathrm{O}$ & 0.1 \\
Other elements & $<0.4$ \\
\hline
\end{tabular}

Little experimental data exist on the influence of aluminum on alkali diffusion in silica thin films. Nevertheless, the structure and transport properties of bulk aluminosilicate glasses and melts have been studied extensively in the geochemistry community $[20,21,22,23,24]$. In particular, the structural role of sodium changes progressively from network modifier to charge compensator of $\mathrm{Al}^{3+}$ when alumina is added to a silicate melt [25, 21, 26, 27, 28. Therefore, adding aluminum to a sodium silicate melt with a fixed $\mathrm{Na} / \mathrm{Si}$ ratio increases its viscosity, since less sodium is available to depolymerize the silica network [28, 29].

In this work, we study the influence of the aluminum content in silica thin layers on alkali migration at temperatures close to the glass transition of the glass substrate. In particular, our aim is to identify and characterize the diffusion mechanisms at play at the interface between the glass substrate and the PVD-sputtered silica thin films. Using Secondary Ion Mass Spectroscopy (SIMS), we study experimentally alkali migration at $650^{\circ} \mathrm{C}$ from soda-lime float glass to PVDsputtered alumina-doped silica layers with different values of aluminum doping. Our experimental results are compared with thermodynamic predic- ${ }^{112}$ tions.

\section{Materials and methods}

\subsection{Glass substrates}

Commercial flat soda-lime glass (Saint-Gobain ${ }_{120}$ Planiclear $\left.{ }^{\circledR}\right)$ with a thickness of $2 \mathrm{~mm}$ was used ${ }_{121}$ as substrate. Its composition is given in Table 1 122 Samples were prepared, cleaned with $\mathrm{RBS}^{T M}$ de- ${ }_{123}$ tergent and rinsed with deionized water before thin ${ }_{124}$ film deposition.

\subsection{Silica thin films deposition}

Pure and aluminum-doped silica layers were deposited by Physical Vapor Deposition (PVD) by cathodic magnetron sputtering at room temperature. $\mathrm{Si}$ and $\mathrm{Si}: \mathrm{Al}$ (8\% in weight) targets were used for silica thin films deposition under reactive atmosphere at $2 \mu$ bar in $\mathrm{Ar} / \mathrm{O}_{2}$ plasma. Silica layers containing $0 \%$ and $\sim 4 \%$ (in weight) of $\mathrm{Al}_{2} \mathrm{O}_{3}$ were obtained by using a single target and $\mathrm{SiO}_{2}$ thin films with $0.2 \%$ to $1 \%$ (in weight) of $\mathrm{Al}_{2} \mathrm{O}_{3}$ were obtained by cosputtering with the two targets. Therefore, various silica samples with $\mathrm{Al}_{2} \mathrm{O}_{3}$ concentrations between 0.0 and $4 \%$ in weight (corresponding to 0.0 to $2.4 \%$ in moles) have been elaborated for this study.

The thickness of the films was measured with surface profilometry (DektakXT, Brucker) or atomic force microscopy (Icon, Brucker). Results for silica layers with thicknesses between $100 \mathrm{~nm}$ to 250 $\mathrm{nm}$ are presented here. Several deposition chambers were used for this work depending on the size of the samples and the configuration needed (sputtering or co-sputtering).

\subsection{Thermal treatments}

After deposition on glass, silica thin films were annealed in air at $650^{\circ} \mathrm{C}$ in an electrical furnace. This temperature is in the range of temperatures used industrially for glass tempering or shaping. One should note that it is higher than the glasstransition temperature $(\mathrm{Tg})$ of the substrate $(\sim$ $550^{\circ} \mathrm{C}$ ). Annealing durations between 5 min and 16 hours were used at this temperature. Samples were directly placed in the furnace prepared at $650^{\circ} \mathrm{C}$ and quenched in air at the end of the thermal treatment.

\subsection{Silica thin films characterization}

Quantification of the silica layer was first performed by EPMA (Electron Probe MicroAnalysis) for one thick layer. The measurements were carried out on an SXFive apparatus (CAMECA, France), on samples coated with a thin carbon layer to reduce charging effects. The electrons energies were 5,10 , and $15 \mathrm{keV}$ and the current was $15 n \mathrm{~A}$ in order to avoid any sodium diffusion during the acquisition applied on an area of $2 \times 40 \mu \mathrm{m}$. The X-rays line selected were the following: $\mathrm{Na} \mathrm{K} \alpha, \mathrm{Si}$ $\mathrm{K} \alpha, \mathrm{Al} \mathrm{K} \alpha$ and $\mathrm{O} \mathrm{K} \alpha$. Due to the larger probed depth $(>1 \mu \mathrm{m})$ of the technique compared to layer thickness $(250 \mathrm{~nm})$, modeling was performed using Stratagem software (SAMX, France). The latter 
Table 2: Concentrations (in weight \%) of $\mathrm{SiO}_{2}, \mathrm{Na}_{2} \mathrm{O}$ and $\mathrm{Al}_{2} \mathrm{O}_{3}$ in a $250 \mathrm{~nm}$ thick silica thin film deposited on glass after $1 \mathrm{~h}$ at $650^{\circ} \mathrm{C}$, measured on the same sample by SIMS (in the central zone), EPMA and XPS.

\begin{tabular}{|cccc|c|}
\hline (weight \%) & $\mathrm{SiO}_{2}$ & $\mathrm{Na}_{2} \mathrm{O}$ & $\mathrm{Al}_{2} \mathrm{O}_{3}$ & $\mathrm{Na} / \mathrm{Al}$ (atomic) \\
\hline SIMS & 92.4 & 3.7 & 3.9 & 1.6 \\
XPS & 90.8 & 4.5 & 4.7 & 1.6 \\
EPMA & 89.9 & 5.2 & 4.8 & 1.8 \\
\hline
\end{tabular}

takes into account the in-depth distribution of the ionization function (called phi(roz)) and based on the XPP model which is well adapted for stratified samples 30. Quantification by EPMA is given in Table 2

Furthermore, layer composition for the same sample was estimated by X-ray Photoelectron Spec- 166 troscopy (XPS). The analyses were performed on 167 a NOVA system (Kratos-GB) equipped with a 168 monochromatic $\mathrm{Al} \mathrm{K} \alpha \mathrm{X}$-ray source, operating at 169 $225 \mathrm{~W}$. The collection angle was set at $0^{\circ}$ (normal 170 detection) in order to maximize the probe depth 171 (to $5 \mathrm{~nm}$ in case of such silica-rich material). Re- 172 sults obtained are also given in Table 2.

Since EPMA results consider that the layer com- ${ }_{174}$ position is homogeneous and XPS only probes the 175 layer surface, SIMS depth profiles were carried out 176 for depth-resolved measurements of the composi- 177 tion. Measurements on as-deposited and annealed 178 silica layers were performed on a TOF.SIMS 5179 (ION-TOF GmbH, Münster, Germany). The pri- 180 mary ions $\mathrm{Bi}^{+}$, accelerated at $30 \mathrm{kV}$ were generated 181 by a LMIG (Liquid Metal Ion Gun) operating in 182 high-current bunched mode with a beam current of 183 $3 \mathrm{pA}$ at $16 \mathrm{kHz}$. The scanned area of $50 \times 50 \mu \mathrm{m}^{2}{ }_{184}$ was centered in the middle of the $200 \times 200 \mu \mathrm{m}^{2}{ }_{185}$ sputter area performed by the DSC (Dual Source 186 Column) source generating $\mathrm{Cs}^{+}$. The sputter beam ${ }_{187}$ energy was $2 \mathrm{keV}$ and the applied current was $150 \quad 188$ $n A$. A usual methodology for non-conductive sam- 189 ples was applied: an electron flood gun was used ( $\mathrm{E}_{190}$ $\sim 21 \mathrm{eV}$ ) in order to reduce charging effects during 191 the acquisition in non-interlaced mode (1s sputter- 192 ing, $0.5 \mathrm{~s}$ pause, 2.5s acquisition) 31 .

An example of typical SIMS depth profile is given 194 in Fig. 1. It is generated by the collection of the 195 positive ions coming from the main isotopes ele- 196 ments present within the glass substrate and the 197 layer (i.e.: ${ }^{1} \mathrm{H}^{+},{ }^{30} \mathrm{Si}^{+},{ }^{23} \mathrm{Na}^{+},{ }^{40} \mathrm{Ca}^{+},{ }^{24} \mathrm{Mg}^{+}$, ${ }_{198}$ $\left.{ }^{39} \mathrm{~K}^{+},{ }^{27} \mathrm{Al}^{+},{ }^{120} \mathrm{Sn}^{+}\right)$. Cs was selected as abra- ${ }_{199}$

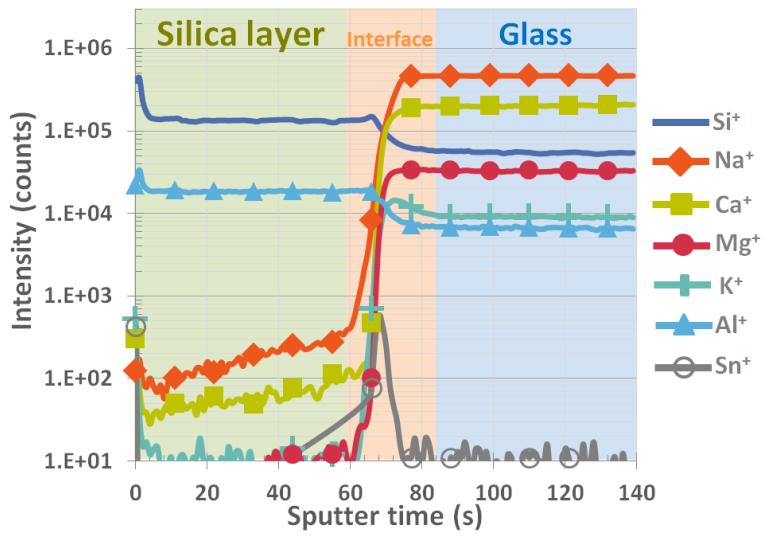

Figure 1: Example of a SIMS depth profile (before calibration) of a silica thin film doped with $0.9-\mathrm{wt} \% \mathrm{Al}_{2} \mathrm{O}_{3}$ asdeposited on glass.

sive species because it induces less artifacts due to alkali-ions migration during depth profiling [32, 33. Only monoatomic ions (as opposed to polyatomic clusters) were followed to generate the composition depth profiles, in order to increase the sensitivity within the silica layer 34 . SIMS values at the extreme surface are affected by transitory effects and should not be interpreted 35 .

Depth calibration was obtained from stylus profilometry (Dektak XT, Bruker) performed on two different SIMS craters. The first one stopped at the glass/layer interface determined by the maximum of ${ }^{120} \mathrm{Sn}^{+}$signal. Indeed, tin condensates on the atmospheric side of glass during the floating process (see Fig. 1). We assume that tin is totally oxidized after annealing into $\mathrm{Sn}^{4+}$, which has a negligible mobility [36]. Typical values of the sputtering rate inside the silica layer were between 1.2 and $1.5 \mathrm{~nm} / \mathrm{s}$ depending on (i) the amount of aluminum, (ii) the deposition conditions and (iii) the thermal treatment. The second crater was stopped deeper in the substrate in order to estimate the sputtering rate for the glass substrate (approximately $1.2 \mathrm{~nm} / \mathrm{s}$ ).

For quantitative depth profiling with SIMS (except for hydrogen), the use of relative sensitivity factors (RSF) is necessary for the conversion of intensities into concentrations [37, 14]. The secondary ion yields of SIMS can be strongly dependent on the composition of the matrix. However, according to the author's experience, we made the assumption that matrix effects are comparable in the dense silica thin films and the soda-lime glass substrate. Therefore the determination of relative sensitivity factors has been made from the compo- 
sition of the glass substrate measured by wet chemistry (cf Table 1). Results of the average values of $\mathrm{SiO}_{2}, \mathrm{Na}_{2} \mathrm{O}$ and $\mathrm{Al}_{2} \mathrm{O}_{3}$ content over a central zone (in order to avoid SIMS artifacts) are given in Table 2 Values obtained with these three techniques converge with differences less than $\pm 20 \%$. Consequently, our assumption for SIMS quantification appears to be relevant.

Finally, hydrogen amount was evaluated by Elastic Recoil Detection Analysis (ERDA). The experiment was carried out on the $2.1 \mathrm{MeV}$ Van-der-Graff accelerator AIFIRA (CENBG-France). The ${ }^{4} \mathrm{He}^{+}$ ions produced, impinged the sample surface at grazing incidence and the hydrogen atoms were collected through a filter (in order to stop He ions). The spectra were processed using SIMRA software. SIMS and ERDA results concerning hydrogen will be discussed in Section 4.2 .

\section{Results}

Typical quantified SIMS depth profiles inside silica thin films deposited on glass are presented on Fig. 2. before and after thermal treatment.

As shown on Fig. 2 a and 2a, deposition of silica thin film with our PVD protocol allows us to obtain pure and aluminum-doped silica layers without contamination by the various oxides contained in the glass substrate. Nevertheless, after annealing for one hour at $650^{\circ} \mathrm{C}$ pure or alumina-doped silica layers (Figs. $2 \mathrm{~b}$ and $2 \mathrm{~d}$ ), we observe the migration of sodium and potassium from the glass substrate to the silica layer. On the other hand, alkaline-earth elements such as calcium and magnesium are not measured in significant amounts. Interestingly, the concentration of alkali oxides (both $\mathrm{Na}_{2} \mathrm{O}$ and $\mathrm{K}_{2} \mathrm{O}$ ) after thermal treatment is substantially higher for an $\mathrm{Al}_{2} \mathrm{O}_{3}$-doped silica layer (Fig. $2 \mathrm{~d}$ ) than for a pure silica layer (Fig $2 \mathrm{~b}$ ).

In order to study the relationship between aluminum doping and alkali migration, we extracted the average value of the $\mathrm{Na}_{2} \mathrm{O}$ and $\mathrm{K}_{2} \mathrm{O}$ content (averaged over a central zone in order to avoid SIMS artifacts at interfaces) in doped and pure silica layers. $\mathrm{Na}_{2} \mathrm{O}$ and $\mathrm{K}_{2} \mathrm{O}$ contents are plotted respectively in Fig. 33 and Fig. 3b as a function of $\mathrm{Al}_{2} \mathrm{O}_{3}$ content, for different annealing durations at $650^{\circ} \mathrm{C}$. We observe a clear affine relation between $\mathrm{Al}_{2} \mathrm{O}_{3}$ and alkali oxides concentrations (mol \%), with a best least-square fit given by:

$$
C_{\mathrm{Na}_{2} \mathrm{O}}=1.47 C_{\mathrm{Al}_{2} \mathrm{O}_{3}}+0.22
$$
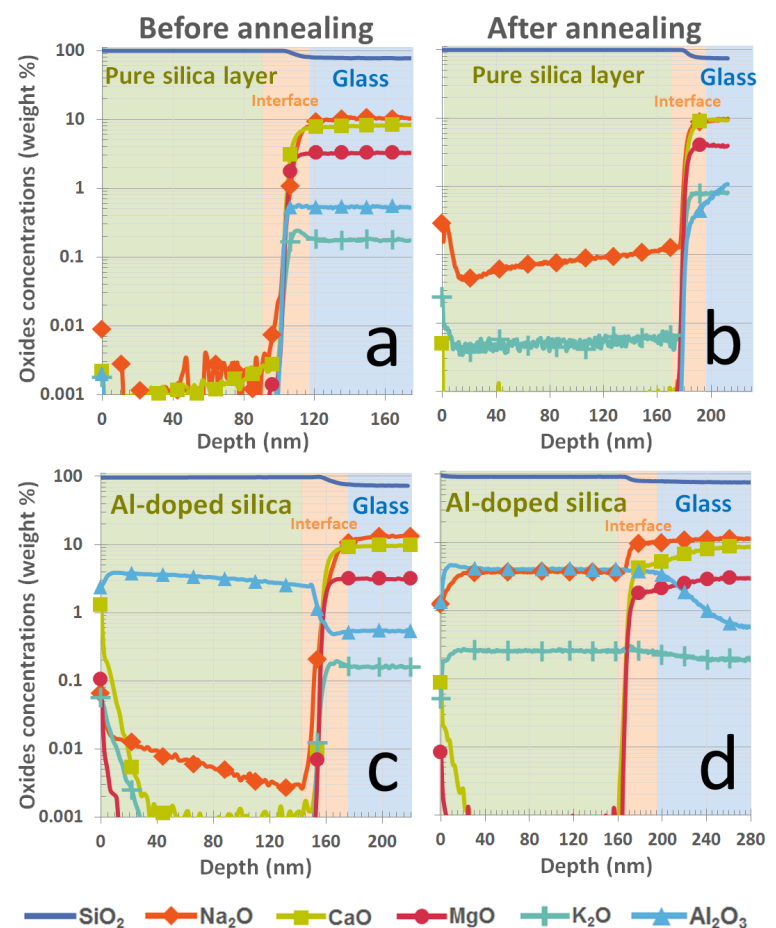

Figure 2: SIMS profiles of silica thin films deposited on glass: a- pure silica layer before annealing, b- pure silica layer after $1 \mathrm{~h}$-annealing at $650^{\circ} \mathrm{C}$, c- 4 -wt $\% \mathrm{Al}_{2} \mathrm{O}_{3}$-doped silica layer before annealing, d- 4 -wt\% $\mathrm{Al}_{2} \mathrm{O}_{3}$-doped silica layer after $1 \mathrm{~h}$-annealing at $650^{\circ} \mathrm{C}$. 


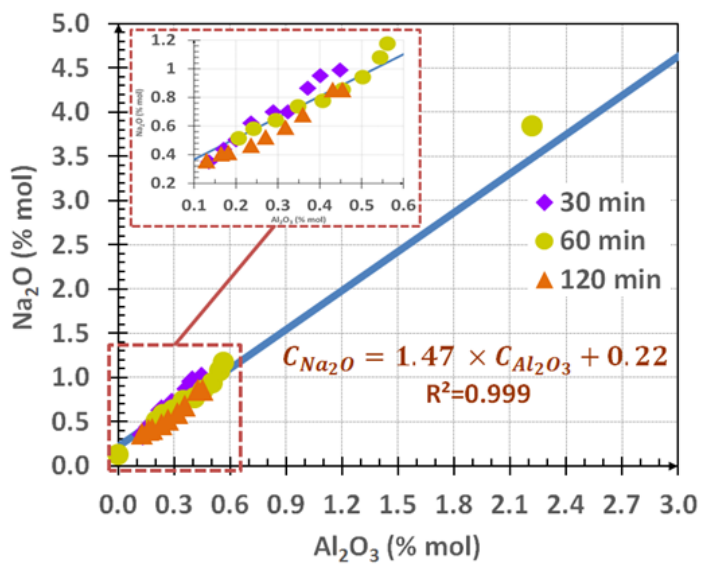

(a)

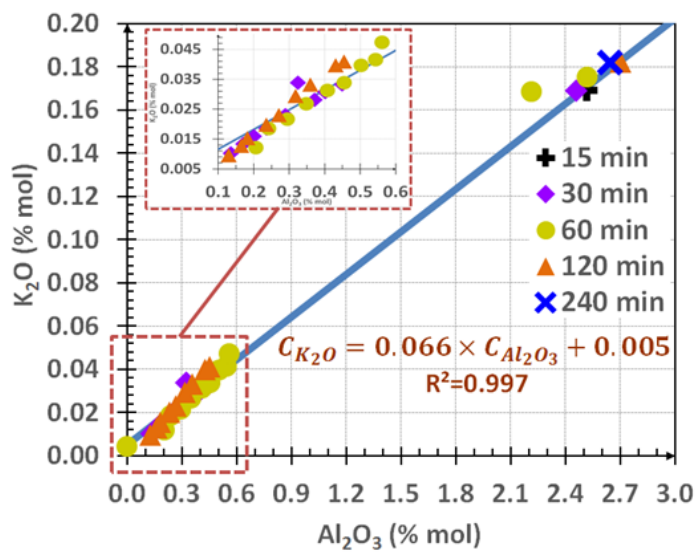

(b)

Figure 3: $\mathrm{Na}_{2} \mathrm{O}$ content (a) and $\mathrm{K}_{2} \mathrm{O}$ content (b) in silica 267 layers after annealing at $650^{\circ} \mathrm{C}$ for different $\mathrm{Al}_{2} \mathrm{O}_{3}$ contents 268 and annealing durations.

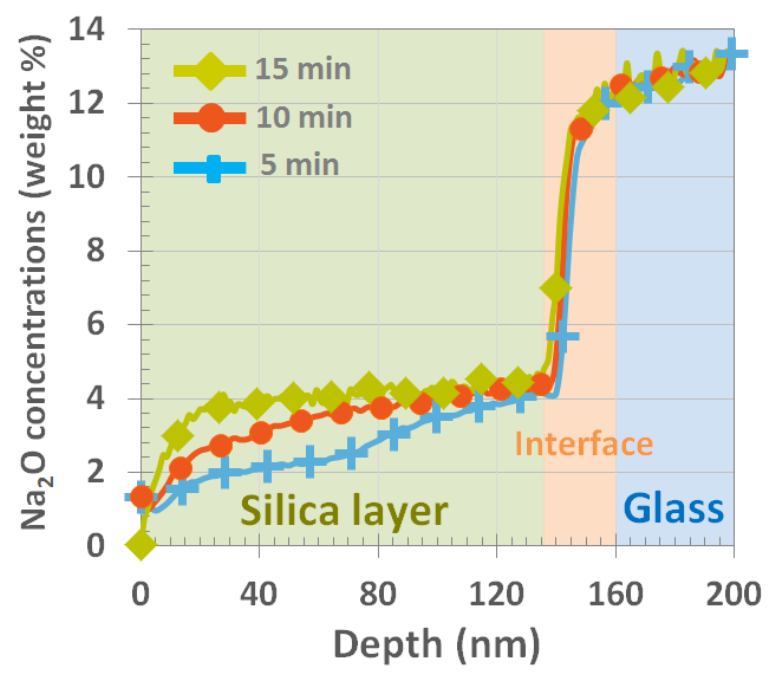

Figure 4: $\mathrm{Na}_{2} \mathrm{O}$ SIMS profiles after diffusion in silica layers for short annealing durations at $650^{\circ} \mathrm{C}$, for a $4-\mathrm{wt} \% \mathrm{Al}_{2} \mathrm{O}_{3}$ doping of the silica layer.

$$
C_{\mathrm{K}_{2} \mathrm{O}}=0.066 C_{\mathrm{Al}_{2} \mathrm{O}_{3}}+0.005
$$

The agreement between experimental data and the affine law is as good for both alkali species. However, the $\mathrm{K}_{2} \mathrm{O}$ content is very low (always < $0.2 \mathrm{~mol} \%$ ), while the $\mathrm{Na}_{2} \mathrm{O}$ content is larger than the $\mathrm{Al}_{2} \mathrm{O}_{3}$ content, with $\sim 1.5$ times more sodium atoms than aluminum atoms in silica after the thermal treatment at $650^{\circ} \mathrm{C}$. Note that the atomic ratio between sodium and potassium is $\sim 25$, while it is 200 in the substrate.

Fig. 3 also shows that, for a given aluminum content, $\mathrm{Na}_{2} \mathrm{O}$ and $\mathrm{K}_{2} \mathrm{O}$ concentrations saturate after an annealing time of about 15 minutes. For shorter annealing durations, Fig. 4 shows that the sodium concentration increases gradually from the interface with glass to the interface with air. After 15 minutes at $650^{\circ} \mathrm{C}$, a uniform sodium concentration profile is observed throughout the layer.

At longer times, the migration of alkali is followed by a dissolution of the silica layer into the substrate, as shown in Fig. 5. where silica profiles are plotted for annealing durations from 15 to 240 minutes. The interface between the silica layer and the glass is marked by a sharp drop of the silica content. The interface shifts gradually from its initial position (green dotted line, which is detected as the position of the $\mathrm{Sn}^{+}$peak), toward the upper surface of the film. This shift denotes a dissolution of the silica layer, due to interdiffusion between the high-silica layer and the substrate with a lower sil- 


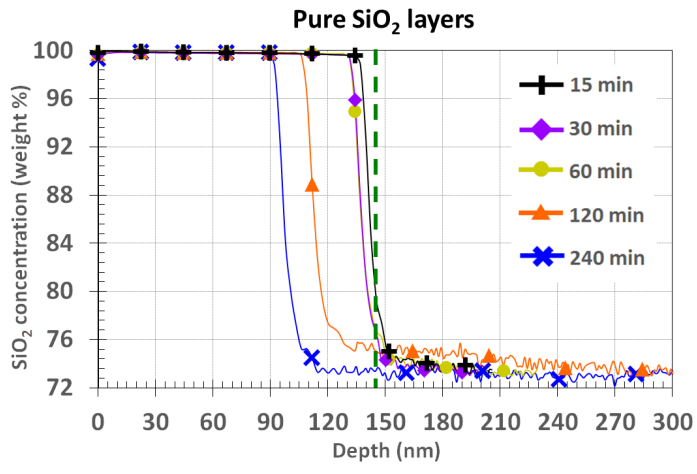

(a)

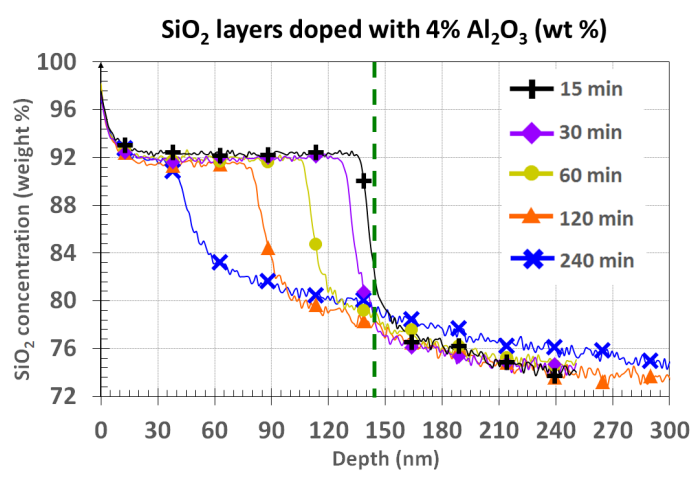

(b)

Figure 5: $\mathrm{SiO}_{2}$ SIMS profiles of (a) a $150 \mathrm{~nm}$ pure silica thin 324 film, and (b) a $150 \mathrm{~nm} \mathrm{Al} \mathrm{O}_{3}$-doped silica thin film for various annealing durations at $650^{\circ} \mathrm{C}$. Interface before annealing (vertical green dotted line) is followed by the maximal value of the $\mathrm{Sn}^{+}$peak during SIMS analysis

324 325 326

ica content. For pure silica layers (with $0.2 \mathrm{~mol} 330$ $\%$ of $\mathrm{Na}_{2} \mathrm{O}$ ), the interface is simply translated (see 331 Fig. 5p), as for the dissolution of a mineral. For 332 the 4-wt\% $\mathrm{Al}_{2} \mathrm{O}_{3}$-doped silica layer, the interface ${ }_{333}$ remains very sharp on the silica layer side, while it ${ }_{334}$ becomes broader on the substrate side, indicating a 335 more pronounced interdiffusion between substrate 336 and layer. Also note that the dissolution is faster 337 for the doped layer than for the pure-silica layer, ${ }_{338}$ since the distance between the initial and the new 339 interface grows approximatively twice faster for the 340 Al-doped layer.

This slow process of dissolution of the silica thin ${ }^{342}$ film into the glass substrate and its dependence ${ }^{343}$ on the aluminum-doping of the layer will be ad- 344 dressed in greater details elsewhere. In the following section, we focus the discussion on the effect 345 of aluminum-doping on the migration of alkali ions 346 from the glass substrate to the silica layer.

\section{Discussion}

\subsection{Mechanism of alkali migration}

Our experiments at $650^{\circ} \mathrm{C}$ demonstrate that alkali ions such as $\mathrm{Na}^{+}$and $\mathrm{K}^{+}$diffuse from glass to silica thin films. As shown in Figs. 3 and 4 alkali ions concentrations are already equilibrated in silica layers after a few minutes at $650^{\circ} \mathrm{C}$ independently of the $\mathrm{Al}_{2} \mathrm{O}_{3}$ content, so that the diffusion length is larger than the 150 -nm-width of the silica layer. Previous studies of sodium diffusion in bulk silica glass found diffusivities between $3.10^{-15}$ and $3.10^{-11} \mathrm{~m}^{2} \cdot \mathrm{s}^{-1}[2,38,39,40$. The discrepancy between diffusivity values in different experiments was attributed to the variable hydroxyl content of the silica glasses 39], depending on its elaboration process. The presence of $\mathrm{H}^{+}$in silica was found to decrease the mobility of $\mathrm{Na}^{+}$, an illustration of the mixed-alkali effect 41. Even the smallest diffusivity value obtained in previous studies $\left(3.10^{-15}\right)$ gives a diffusion distance of 1 micron in 10 minutes, that is a diffusion length greater than the width of the silica layer. Therefore, constant sodium profiles after 15 minutes at $650^{\circ} \mathrm{C}$ are consistent with literature values for sodium diffusivity.

For bulk aluminosilicate glasses containing $\mathrm{Na}_{2} \mathrm{O}$ and/or $\mathrm{K}_{2} \mathrm{O}$, interdiffusion between melts of differing alkali concentrations is mostly governed by the exchange of alkali ions with $\mathrm{SiO}_{2}$ [42, 43, 44, 45]. Such exchanges, if present, would result in a variation of the $\mathrm{Si} / \mathrm{Al}$ ratio before and after sodium migration. However, during alkali-ions migration, we observe that the atomic ratio $\mathrm{Si} / \mathrm{Al}$ in the silica layer remains constant, as shown in the $\mathrm{SiO}_{2}{ }^{-}$ $\mathrm{Al}_{2} \mathrm{O}_{3}-\mathrm{Na}_{2} \mathrm{O}$ phase diagram in Fig. 6 (red dotted arrows). Therefore, the migration of sodium and potassium corresponds to a dilution of the initial composition of the layer, and not to a counter flux of alkali and $\mathrm{Si}$ or $\mathrm{Al}$.

Nevertheless, electro-neutrality requires a net flux of another charged species to compensate the charge of additional alkali. Previous studies in barrier layers [2, 19] suggested that a counter-flux of protons enables sodium migration into silica. The influence of water concentration on sodium migration had also been studied in bulk silica [46, 39. The influence of water is discussed in more details in the next paragraphs.

\subsection{Interdiffusion between protons and alkali ions}

Water is one of the most common important impurity found in PVD sputtered thin films. It's ori- 


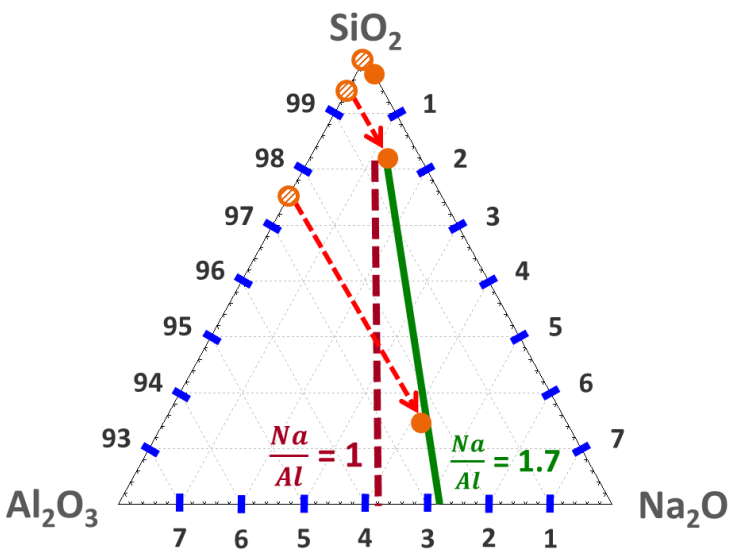

Figure 6: Zoom of the phase diagram in the ternary system $\mathrm{SiO}_{2}-\mathrm{Al}_{2} \mathrm{O}_{3}-\mathrm{Na}_{2} \mathrm{O}$ between 92 and $100 \% \mathrm{SiO}_{2}$ in mol $\%$. Empty circles correspond to silica thin films before annealing and filled circles to silica thin films after sodium migration. Red dotted arrows correspond to a constant Si/Al atomic ratio.

Table 3: Hydrogen content in silica films as measured by 366 ERDA for a pure silica layer or a 2.4-mol\% $\mathrm{Al}_{2} \mathrm{O}_{3}$-doped silica layer. Analyses are performed on samples before and after thermal treatments 30 minutes at $650^{\circ} \mathrm{C}$.

\begin{tabular}{|c|c|c|}
\hline $\begin{array}{c}\mathrm{H} \text { content } \\
(\mathrm{mol} \%)\end{array}$ & $\begin{array}{c}\text { Before } \\
\text { annealing }\end{array}$ & $\begin{array}{c}\text { After } \\
\text { annealing }\end{array}$ \\
\hline pure silica & $\begin{array}{c}0.40 \% \\
\approx 6000 \mathrm{ppm} \mathrm{H}_{2} \mathrm{O}\end{array}$ & $<0.1 \%$ \\
\hline Al-doped silica & $\begin{array}{c}0.38 \% \\
\end{array}$ & $<0.1 \%$ \\
\hline
\end{tabular}

gin could be outgassing phenomenon of the deposition chamber walls during the process and sur- 378 face adsorption during storage due to the porosity 379 of the layers. Table 3 report ERDA measurements 380 that could be performed on two samples (one pure- 381 silica layer and one 2.4-mol\% $\quad \mathrm{Al}_{2} \mathrm{O}_{3}$-doped layer) ${ }_{382}$ before and after thermal annealing. They first show 383 that significant hydrogen contents (of the order of 384 half percent) can be found in the deposited silica 385 or aluminum-doped silica thin films. Interestingly, 386 this hydrogen content shows a sharp decrease after ${ }_{387}$ thermal treatment.

The loss of $\mathrm{H}$ upon annealing is clearly consistent 389 with a scenario of interdiffusion between hydrogens 390 of the layer and alkali ions of the glass substrate. In 391 order to test this hypothesis further we performed 392 SIMS measurements on samples annealed at a lower 393 temperature, $\mathrm{T}=550^{\circ} \mathrm{C}$. The slowing of the dynam- 394

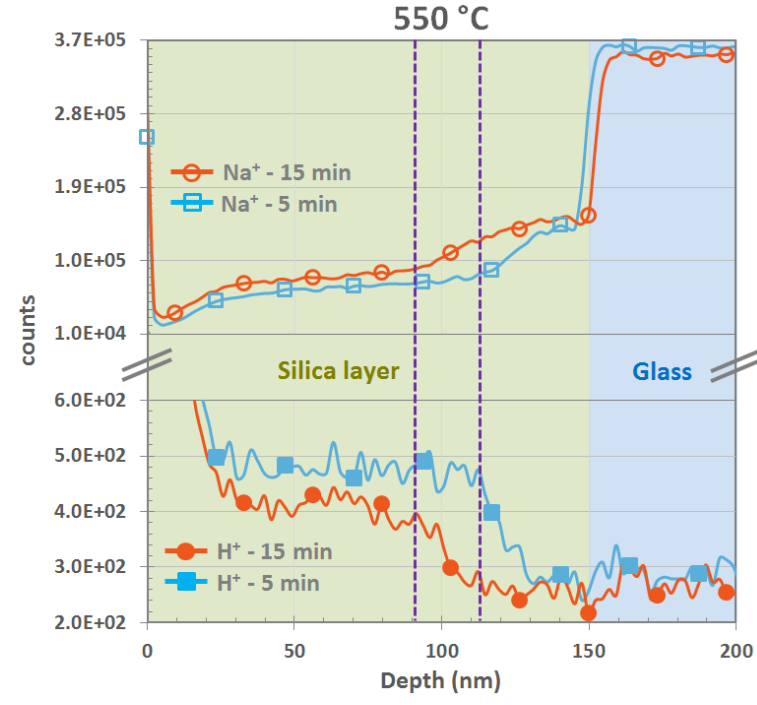

Figure 7: $\mathrm{Na}^{+}$and $\mathrm{H}^{+}$SIMS profiles after 5 and 15 minutes at $550^{\circ} \mathrm{C}$, for a 4 -wt $\% \mathrm{Al}_{2} \mathrm{O}_{3}$-doping of the silica layer.

ics thus allowed us to observe earlier steps of the diffusion process, i.e. before saturation of the alkali content in the film. We show in Fig. 7 SIMS profiles in a 4-wt\% $\mathrm{Al}_{2} \mathrm{O}_{3}$-doped silica thin film of $\mathrm{H}^{+}$and $\mathrm{Na}^{+}$ions after $5 \mathrm{~min}$. and $15 \mathrm{~min}$. of thermal treatment at $550^{\circ} \mathrm{C}$, respectively. Although not quantitative, these profiles show a clear trend: an interdiffusion front of the two species moving from the glass substrate interface toward the surface of the thin film.

\subsection{Equilibrium sodium concentration in silica layer}

Since alkali concentration is constant after 15 minutes in the silica layers, alkali species are at thermodynamic equilibrium and should have a similar chemical potential in the substrate and in the silica layer. Using the software Factsage ${ }^{\circledR}$ with the FT oxides database and especially the FT oxidSLAGA module (A-Slag-liq all oxides) developed for silicate systems (47, 48, 49, 50, 51), we computed the activity of sodium in the substrate and in the silica layer, for various aluminum and sodium concentrations. In order to stress the crucial effect of the water content in silica films on the alkali diffusion from the glass substrate, we present below results obtained in absence and in presence of water in the films.

The activity of sodium at $650^{\circ} \mathrm{C}$ as a function of sodium concentration in a dry silica layer is repre- 
sented in Fig. 8a, for three different aluminum dop- 446 ing contents. We observe that increasing the alu- 447 minum content decreases the activity of sodium, a 448 result that has been obtained experimentally in the ${ }_{449}$ literature 52 and that is explained by the smaller 450 sodium content in network-modifying role. A sharp ${ }_{451}$ increase of sodium activity occurs when the mo- ${ }_{452}$ lar concentration of sodium equates the one of alu- 453 minum. Qualitatively, this corresponds to the con- 454 centration at which sodium ions charge-compensate 455 all aluminum tetrahedral units. Therefore, the ac- 456 tivity of sodium in the layer depends strongly on 457 the aluminum content. In Fig. 8a, the activity of 458 sodium in the glass substrate is represented as a red ${ }_{459}$ dotted line.

We define the theoretical sodium equilibrium concentration as the concentration at which chemical potentials are the same in the substrate and the silica layer. The sodium equilibrium concentration is plotted in Fig. 8. (orange line) as a function of aluminum content of the silica layer. We observe an affine (almost linear) relation as in our experiments, but with a different $\mathrm{Na} / \mathrm{Al}$ atomic ratio: thermodynamic calculations predict a ratio close to one (which amounts to compensating all aluminum tetrahedra), whereas a ratio of 1.5 is observed in our experiments. This means that (in experiments) $1 / 3$ of sodium ions in the silica layer are not charge compensators of aluminum tetrahedra, but network modifiers bound to non-bridging oxygens.

However, it is known [53, 54, 55, 56] that the pres- ${ }_{474}$ ence of water modifies the structure of aluminosili- 475 cate glasses and melts, hence the activity of sodium 476 in these materials. This strong effect is illustrated 477 in Fig. 8b, where we plotted the activity of sodium 478 in a silica layer as in Fig. 8a, for a layer composi- 479 tion including both the aluminum doping and the ${ }_{480}$ presence of water (we arbitrarily chose $6000 \mathrm{ppm}$ of ${ }_{481}$ water as measured by ERDA in a $\mathrm{Al}_{2} \mathrm{O}_{3}$-doped sil- ${ }_{482}$ ica layer - $2.4 \mathrm{~mol} \%$ - cf Table 3 . but we found that ${ }_{483}$ the value of sodium activity has a very weak depen- ${ }_{484}$ dence with water between 100 ppm to 20000 ppm). ${ }_{485}$ Calculations of sodium activities in presence of wa- 486 ter are also performed using Factsage $B$ with the ${ }_{487}$ FT oxides database but with the FT oxid-SLAGE ${ }_{488}$ module (E-Slag-liq with $\mathrm{H} 2 \mathrm{O} / \mathrm{OH}$ ) which can take 489 into account interactions of water with the silicate 490 network [57, 58]. Comparing Fig. 8a and Fig. 8b 491 shows that: (i) for a pure silica layer, the activ- 492 ity of sodium does not change with or without wa- 493 ter, (ii) but for an aluminum-doped silica layer, the 494 activity of sodium changes drastically when water is added. Indeed, the evolution of sodium activity is more gradual in the presence of water, suggesting that water-induced network depolymerization 53, 54 results in a greater diversity of sites for sodium. The sodium equilibrium concentration in the presence of water is plotted in Fig. 8p (violet line). We observe an affine scaling with aluminum content as in water-free layers, but with a greater slope. A least-square fit gives a value of 1.46 for the $\mathrm{Na} / \mathrm{Al}$ ratio, which is very close to the experimental value (1.47) of Fig. 3a. Therefore, a quantitative prediction of sodium content in the layer can be obtained by balancing sodium activities in substrate and layer, if the presence of some water in the layer is taken into account.

\section{Conclusions}

In this work we have studied the diffusion processes occurring in silica-based thin films deposited on float glass during thermal treatments above the glass-transition temperature of the glass substrate. Using SIMS analysis, we have quantified the migration of sodium and potassium in silica thin films and shown that their concentration reaches a saturation value after only 15 minutes of annealing at $650^{\circ} \mathrm{C}$. The aluminum doping of the silica film has been shown to strongly enhance (with a linear scaling) the diffusion of alkali ions from the glass substrate.

The presence of water in the as-deposited silica films (validated by ERDA measurements) has appeared to be a key element of understanding of this phenomenon. First we could identify an interdiffusion process between the protons of the film and the sodium ions of the glass substrate. Then, taking water into account was shown to drastically modify the thermodynamic activity of sodium in the layer and thus its final equilibrium concentration.

In particular the latter exceeds the aluminum concentration of the thin film. The sodium ions in the aluminum-doped silica layer thus exist not only as charge compensators of the aluminum ions inserted in the silica network but also as network modifiers. As illustrated in Fig. 5, this depolymerization effect of aluminum on the silica network is likely to strongly affect the slower homogenization process (thin film dissolution) occurring at long times and will be addressed in more detailed in a future study. 


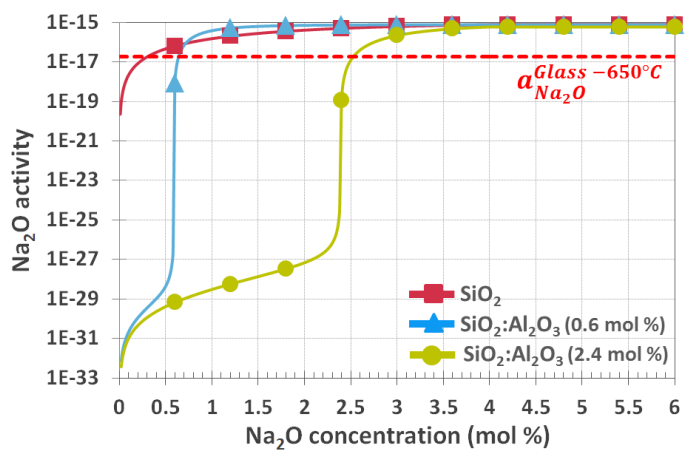

(a)

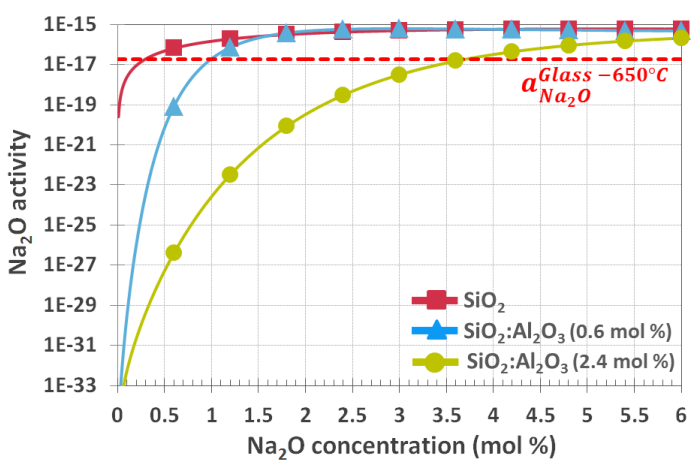

(b)

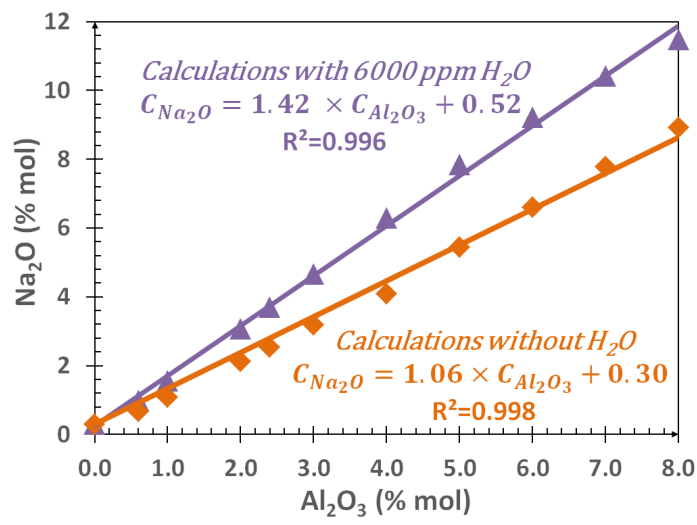

(c)

Figure 8: Energetics of sodium - (a) $\mathrm{Na}_{2} \mathrm{O}$ activity in sil- 541 ica layer at $650^{\circ} \mathrm{C}$ as a function of $\mathrm{Na}_{2} \mathrm{O}$ concentration, for 542 different aluminum doping, and for free sodium atoms (i.e., 543 network modifiers and not charge compensators). Calcula- 544 tions are made with Factsage ${ }^{\circledR}$ software, using the FT oxides 545 database. The red dotted line marks the value of $\mathrm{Na}_{2} \mathrm{O}$ activ- 546 ity at $650^{\circ} \mathrm{C}$ in the float glass substrate. (b) Same as (a), for 547 silica layers containing 6000ppm of water. (c) Equilibrium 548 sodium concentration in the silica layer as a function of alu- 549 minum doping, for dry layers (orange) and water-containing 550 layers (violet).

\section{Acknowledgments}

The authors gratefully acknowledge Thierry Crétin, Corinne Papret and Régine Faure for SIMS measurements at Saint-Gobain Recherche in Aubervilliers (France), Biophy Research in Fuveau (France) for XPS analysis and ARCANE-CENBG in Bordeaux (France) for ERDA analysis. The authors also acknowledge the experimental help of Raphaël Danguillaume, Anne Lelarge, Benoît Louis and Jean-Paul Rousseau, as well as enlightening discussions with Corinne Claireaux and Mike Toplis.

\section{References}

[1] S. Ishizuka, A. Yamada, P. J. Fons, H. Shibata, S. Niki, Interfacial alkali diffusion control in chalcopyrite thinfilm solar cells, ACS Appl. Mater. Inter. 6 (16) (2014) 14123-30. doi:10.1021/am503480m

[2] N. Janke, O. Grassme, R. Weimann, Alkali ion migration control from flat glass substrates, Glass Sci. Tech. 73 (2000) 143-155.

[3] J. H. Scofield, S. Asher, D. Albin, J. Tuttle, M. Contreras, D. Niles, R. Reedy, A. Tennant, R. Noufi, Sodium diffusion, selenization, and microstructural effects associated with various molybdenum back contact layers for CIS-based solar cells, in: 24th IEEE Photovoltaic Specialists Conference, Vol. 1, pp. 164-167. doi:10.1109/wcpec.1994.519833

[4] K. Durose, M. A. Cousins, D. S. Boyle, J. Beier, D. Bonnet, Grain boundaries and impurities in $\mathrm{CdTe} / \mathrm{CdS}$ solar cells, Thin Solid Films 403-404 (2002) 396-404. doi:10.1016/s0040-6090(01)01518-8

[5] M. Emziane, K. Durose, D. P. Halliday, N. Romeo, A. Bosio, The distribution of impurities in the interfaces and window layers of thin-film solar cells, J. Appl. Phys. 97 (11) (2005) 114910. doi:10.1063/1.1921344

[6] L. Kranz, J. Perrenoud, F. Pianezzi, C. Gretener, P. Rossbach, S. Buecheler, A. Tiwari, Effect of sodium on recrystallization and photovoltaic properties of CdTe solar cells, Sol. Energ. Mat. Sol. C. 105 (2012) 213-219. doi:10.1016/j.solmat.2012.06.019

[7] J. Kulczyk-Malecka, P. J. Kelly, G. West, G. C. B. Clarke, J. A. Ridealgh, Investigations of diffusion behaviour in Al-doped zinc oxide and zinc stannate coatings, Thin Solid Films 520 (5) (2011) 1368-1374. doi: 10.1016/j.tsf.2011.08.076

[8] J. Kulczyk-Malecka, P. J. Kelly, G. West, G. C. B. Clarke, J. A. Ridealgh, Diffusion studies in magnetron sputter deposited silicon nitride films, Surf. Coat. Tech. 255 (2014) 37-42. doi:10.1016/j.surf coat.2013.11. 027.

[9] J.-M. Lee, B.-H. Choi, M.-J. Ji, Y.-T. An, J.-H. Park, J.-H. Kwon, B.-K. Ju, Effect of barrier layers on the properties of indium tin oxide thin films on soda lime glass substrates, Thin Solid Films 517 (2009) 40744077. doi:10.1016/j.tsf.2009.01.149

[10] M. N. Ghazzal, E. Aubry, N. Chaoui, D. Robert, Effect of $\mathrm{SiN}_{x}$ diffusion barrier thickness on the structural properties and photocatalytic activity of $\mathrm{TiO}_{2}$ films obtained by sol-gel dip coating and reactive magnetron 
sputtering, Beilstein J. Nanotech. 6 (2015) 2039-45. 619 doi:10.3762/bjnano.6.207

[11] F. P. Fehlner, N. J. Binkowski, K. R. Salisbury, L. But- 62 ton, Alumina barrier layers on LCD glass, J. Non-Cryst. 622 Solids 195 (1996) 89-94. doi:10.1016/0022-3093(95) 623 00473-4

[12] F. P. Fehlner, Thin films on glass for liquid crystal dis- 625 plays, J. Non-Cryst. Solids 218 (1997) 360-367. doi: 626 10.1016/S0022-3093(97)00243-3 627

[13] S. Sonderby, P. L. Popa, J. Lu, B. H. Christensen, 628 K. P. Almtoft, L. P. Nielsen, P. Eklund, Strontium diffu- 629 sion in magnetron sputtered gadolinia-doped ceria thin 630 film barrier coatings for solid oxide fuel cells, Adv. En- 631 ergy Mater. 3 (7) (2013) 923-929. doi:10.1002/aenm. 632 201300003

[14] S. Dreer, P. Wilhartitz, K. Piplits, K. Mayerhofer, J. Foisner, H. Hutter, Quantitative SIMS depth pro- 635 filing of diffusion barrier gate-oxynitride structures in 636 TFT-LCDs, Anal. Bioanal. Chem. 379 (2004) 599-604. 637 doi:10.1007/s00216-003-2468-y

[15] J. W. Osenbach, S. S. Voris, Sodium diffusion in 639 plasma-deposited amorphous oxygen-doped silicon ni- 640 tride (a-SiON:H) films, J. Appl. Phys. 63 (1988) 4494. 641 doi:10.1063/1.340144.

[16] F Guanghui, D Jiafeng, P. Donghui, H Ouli, The migration of alkali ions from glass substrates coated with 644 sol-gel barrier films, J. Non-Cryst. Solids 112 (1989) 645 454457.

[17] B. M. Davies, K. H. Pannell, S. P. Albright, Diffusion 647 barrier of sol-gel derived silica for sprayed tin oxide film 648 on soda-lime glass, J. Mater. Res. 9 (01) (2011) 226-228. 649 doi:10.1557/jmr.1994.0226

[18] J. Wolfe, C. Boehmler, J. Hofmann, Method for 651 coating substrates with silicon based compounds - 652 EP0502068B1 (04 1995).

[19] R. J. Araujo, F. P. Fehlner, Sodium redistribution be- 654 tween oxide phases, J. Non-Cryst. Solids 197 (1996) 655 154-163. doi:10.1016/0022-3093(95)00632-X. 656

[20] S. K. Lee, J. F. Stebbins, The structure of aluminosil- 657 icate glasses: High-resolution ${ }^{17} \mathrm{O}$ and ${ }^{27} \mathrm{Al} \mathrm{MAS}$ and 658 3QMAS NMR study, J. Phys. Chem. B 104 (17) (2000) 659 4091-4100.

[21] S. K. Lee, J. F. Stebbins, The distribution of sodium 661 ions in aluminosilicate glasses: a high-field Na-23 MAS 662 and 3Q MAS NMR study, Geochim. Cosmochim. Ac. 663 67 (9) (2003) 1699-1709.

[22] S. K. Lee, J. F. Stebbins, Effects of the degree of poly- 665 merization on the structure of sodium silicate and alu- 666 minosilicate glasses and melts: An ${ }^{17} \mathrm{O}$ NMR study, 667 Geochim Cosmochim. Ac. 73 (4) (2009) 1109-1119. 668

[23] Y. Zhang, H. Ni, Y. Chen, Diffusion data in silicate 669 melts, Rev. Mineral. Geochem. 72 (1) (2010) 311-408. 670

[24] Y. Liang, Multicomponent diffusion in molten silicates: 671 theory, experiments, and geological applications, Re- 672 views in Mineralogy and Geochemistry 72 (1) (2010) 673 409-446.

[25] A. M. George, J. F Stebbins, Dynamics of Na in sodium 675 aluminosilicate glasses and liquids, Phys. Chem. Miner. 676 23 (8) (1996) 526-534.

[26] J. R. Allwardt, B. T. Poe, J. F. Stebbins, The effect of 678 fictive temperature on $\mathrm{Al}$ coordination in high-pressure 679 $(10 \mathrm{GPa})$ sodium aluminosilicate glasses, Am. Mineral. 680 90 (8-9) (2005) 1453-1457.

[27] Y. Xiang, J. Du, M. M. Smedskjaer, J. C. Mauro, Struc- 682 ture and properties of sodium aluminosilicate glasses 683 from molecular dynamics simulations, J. Chem. Phys. 139 (4) (2013) 044507.

[28] C. Le Losq, D. R. Neuville, P. Florian, G. S. Henderson, D. Massiot, The role of $\mathrm{Al}^{3+}$ on rheology and structural changes in sodium silicate and aluminosilicate glasses and melts, Geochim. Cosmochim. Ac. 126 (2014) 495517. doi:10.1016/j.gca.2013.11.010

[29] M. J. Toplis, D. B. Dingwell, T. Lenci, Peraluminous viscosity maxima in $\mathrm{Na}_{2} \mathrm{O}-\mathrm{Al}_{2} \mathrm{O}_{3}-\mathrm{SiO}_{2}$ liquids: The role of triclusters in tectosilicate melts, Geochim. Cosmochim. Ac. 61 (13) (1997) 2605-2612.

[30] J. L. Pouchou, F. Pichoir, Analyse d'échantillons stratifiés à la microsonde électronique, Le Journal de Physique Colloques 45 (C2) (1984) 47-50. doi:10. 1051/jphyscol:1984212

[31] Z. Wang, K. Jin, Y. Zhang, F. Wang, Z. Zhu, ToF-SIMS depth profiling of insulating samples, interlaced mode or non-interlaced mode?, Surf. Interface Anal. 46 (S1) (2014) 257-260. doi:10.1002/sia.5419

[32] Y. Yamamoto, N. Shimodaira, SIMS depth profile analysis of sodium in silicon dioxide, Appl. Surf. Sci. 255 (4) (2008) 860-862. doi:10.1016/j.apsusc.2008.05.069.

[33] S. Krivec, T. Detzel, M. Buchmayr, H. Hutter, On the temperature dependence of $\mathrm{Na}$ migration in thin $\mathrm{SiO}_{2}$ films during ToF-SIMS $\mathrm{O}_{2}{ }^{+}$depth profiling, Appl. Surf. Sci. 257 (1) (2010) 25-32. doi:10.1016/j.apsusc. 2010.06 .019

[34] B. Saha, P. Chakraborty, $\mathrm{MCs}_{n}{ }^{+}$-SIMS: An innovative approach for direct compositional analysis of materials without standards, Energy Proced. 41 (2013) 80-109. doi:10.1016/j.egypro.2013.09.009

[35] U. Hoffmann, G. Heide, G. H. Frischat, Reactions between solgel coatings and some technical glass substrates during consolidation, Journal of Non-Crystalline Solids 351 (43-45) (2005) 3562-3569. doi:10.1016/j. jnoncrysol.2005.08.032

[36] G. Heide, C. Muller-Fildebrandt, D. Moseler, G. Frischat, W. Meisel, A. Maldener, A. ZouineThimm, F. Rauch, Tin in float glass: A diffusionreaction model based on surface analysis explains the tin hump, Glass Science and Technology - Glastechnische Berichte 73 (2000) 321-330.

[37] U. Breuer, H. Holzbrecher, M. Gastel, J. S. Becker, H.J. Dietze, Comparative studies of $\mathrm{MCs}^{+}-\mathrm{SIMS}$ and $\mathrm{e}^{-}-$ beam SNMS for quantitative analysis of bulk materials and layered structures, Fresen. J. Anal. Chem. 353 (3) (1995) 372-377. doi:10.1007/bf00322072.

[38] G. H. Frischat, Sodium diffusion in $\mathrm{SiO}_{2}$ glass, J. Am. Ceramic Soc. 51 (9) (1968) 528-530.

[39] L. Tian, R. Dieckmann, C.-Y. Hui, Y.-Y. Lin, J. G. Couillard, Effect of water incorporation on the diffusion of sodium in type I silica glass, J. Non-Cryst. Solids 286 (3) (2001) 146-161.

[40] L. Tian, R. Dieckmann, Incorporation of water into glasses and its influence on the diffusion of cations, including the creation of diffusion barriers, J. Non-Cryst. Solids 352 (6) (2006) 679-689.

[41] J. Isard, The mixed alkali effect in glass, J. Non-Cryst. Solids 1 (3) (1969) 235-261.

[42] S. Chakraborty, D. B. Dingwell, D. C. Rubie, Multicomponent diffusion in ternary silicate melts in the system $\mathrm{K}_{2} \mathrm{O}-\mathrm{Al}_{2} \mathrm{O}_{3}-\mathrm{SiO}_{2}$ : I. experimental measurements, Geochim. Cosmochim. Ac. 59 (2) (1995) 255-264. doi : 10.1016/0016-7037(94)00283-r

[43] S. Chakraborty, D. B. Dingwell, D. C. Rubie, Multicom- 
ponent diffusion in ternary silicate melts in the system 749 $\mathrm{K}_{2} \mathrm{O}-\mathrm{Al}_{2} \mathrm{O}_{3}-\mathrm{SiO}_{2}$ : II. mechanisms, systematics, and ge- 750 ological applications, Geochim. Cosmochim. Ac. 59 (2) 751 (1995) 265-277. doi:10.1016/0016-7037(95) 00284-7

[44] J. E. Mungall, C. Romano, D. B. Dingwell, Multicomponent diffusion in the molten system $\mathrm{K}_{2} \mathrm{O}-\mathrm{Na}_{2} \mathrm{O}$ $\mathrm{Al}_{2} \mathrm{O}_{3}-\mathrm{SiO}_{2}-\mathrm{H}_{2} \mathrm{O}$, Am. Mineral. 83 (1998) 685-699. doi:10.2138/am-1998-7-802

[45] C. Guo, Y. Zhang, Multicomponent diffusion in silicate melts: $\mathrm{SiO}_{2}-\mathrm{TiO}_{2}-\mathrm{Al}_{2} \mathrm{O}_{3}-\mathrm{MgO}-\mathrm{CaO}-\mathrm{Na}_{2} \mathrm{O}-\mathrm{K}_{2} \mathrm{O}$ system, Geochim. Cosmochim. Ac. 195 (2016) 126-141.

[46] J. Mecha, J. Steinmann, et al., Mobility of sodium ions in silica glass of different $\mathrm{OH}$ content, J. Am. Ceramic Soc. 62 (7-8) (1979) 343-346.

47] C. W. Bale, P. Chartrand, S. A. Degterov, G. Eriksson, K. Hack, R. Ben Mahfoud, J. Melanon, A. D. Pelton, S. Petersen, Factsage thermochemical software and databases, Calphad 26 (2) (2002) 189-228. doi: 10.1016/s0364-5916(02)00035-4

[48] C. W. Bale, E. Blisle, P. Chartrand, S. A. Decterov, G. Eriksson, K. Hack, I. H. Jung, Y. B. Kang, J. Melanon, A. D. Pelton, C. Robelin, S. Petersen, Factsage thermochemical software and databases recent developments, Calphad 33 (2) (2009) 295-311. doi:10.1016/j.calphad.2008.09.009

[49] G. Eriksson, A. Pelton, Critical evaluation and optimization of the thermodynamic properties and phase diagrams of the $\mathrm{CaO}-\mathrm{Al}_{2} \mathrm{O}_{3}, \mathrm{Al}_{2} \mathrm{O}_{3}-\mathrm{SiO}_{2}$ and $\mathrm{CaO}-$ $\mathrm{Al}_{2} \mathrm{O}_{3}-\mathrm{SiO}_{2}$ systems, Metall. Trans. 24B (1993) 807816.

50] G. Eriksson, P. Wu, A. Pelton, Critical evaluation and optimization of the thermodynamic properties and phase diagrams of the $\mathrm{MgO}-\mathrm{Al}_{2} \mathrm{O}_{3}, \mathrm{MnO}-\mathrm{Al}_{2} \mathrm{O}_{3}, \mathrm{FeO}-$ $\mathrm{Al}_{2} \mathrm{O}_{3}, \mathrm{Na}_{2} \mathrm{O}-\mathrm{Al}_{2} \mathrm{O}_{3}$ and $\mathrm{K}_{2} \mathrm{O}-\mathrm{Al}_{2} \mathrm{O}_{3}$ systems, Calphad Journal 17 (1993) 189-206.

[51] P. Wu, G. Eriksson, A. Pelton, Critical evaluation and optimization of the thermodynamic properties and phase diagrams of the $\mathrm{Na}_{2} \mathrm{O}-\mathrm{SiO}_{2}$ and $\mathrm{K}_{2} \mathrm{O}-\mathrm{SiO}_{2}$ systems, J. Am. Ceram. Soc. 76 (1993) 2059-2064.

[52] S. Abdelouhab, R. Podor, C. Rapin, M. Toplis, P. Berthod, M. Vilasi, Determination of $\mathrm{Na}_{2} \mathrm{O}$ activities in silicate melts by EMF measurements, J. Non-Cryst. Solids 354 (26) (2008) 3001-3011.

[53] Q. Zeng, H. Nekvasil, C. P. Grey, In support of a depolymerization model for water in sodium aluminosilicate glasses:: Information from NMR spectroscopy, Geochim. Cosmochim. Ac. 64 (5) (2000) 883-896.

[54] E. Robert, A. Whittington, F. Fayon, M. Pichavant, D. Massiot, Structural characterization of waterbearing silicate and aluminosilicate glasses by highresolution solid-state NMR, Chem. Geol. 174 (1) (2001) $291-305$.

55] X. Xue, M. Kanzaki, Structure of hydrous aluminosilicate glasses along the diopside-anorthite join: A comprehensive one-and two-dimensional ${ }^{1} \mathrm{H}$ and ${ }^{27} \mathrm{Al} \mathrm{NMR}$ study, Geochim. Cosmochim. Ac. 72 (9) (2008) 23312348.

[56] W. J. Malfait, X. Xue, The nature of hydroxyl groups in aluminosilicate glasses: Quantifying $\mathrm{Si}-\mathrm{OH}$ and $\mathrm{Al}-\mathrm{OH}$ abundances along the $\mathrm{SiO}_{2}-\mathrm{NaAlSiO}_{4}$ join by ${ }^{1} \mathrm{H},{ }^{27} \mathrm{Al}-$ ${ }^{1} \mathrm{H}$ and ${ }^{29} \mathrm{Si}^{-1} \mathrm{H}$ NMR spectroscopy, Geochim. Cosmochim. Ac. 74 (2) (2010) 719-737.

[57] I.-H. Jung, Thermodynamic modeling of gas solubility in molten Slags (I) - Water, ISIJ Int 46 (2006) 15871593.
[58] A. Pelton, Thermodynamic calculation of gas solubilities in oxide melts and glasses, Glastechnische Berichte 72 (1999) 214-226. 